\title{
First record of microfilaria in the blood of black caiman Melanosuchus niger (Crocodylia: Alligatoridae) specimens from the Amazon River basin
}

\author{
A. T. Oliveira ${ }^{a}$, M. Q. C. Santos ${ }^{b}, J$. Pantoja-Lima $^{c}$, M. R. F. Machado ${ }^{\text {, J. R. G. Lemos }}$, \\ M. Tavares-Dias ${ }^{f}$ and P. H. R. Aride \\ anstituto Federal de Educação, Ciência e Tecnologia do Amazonas - IFAM, Campus Manaus Centro - CMC, \\ Avenida Sete de Setembro, 1975, CEP 69020-120, Manaus, AM, Brazil \\ ' Instituto Federal de Educação, Ciência e Tecnologia do Amazonas - IFAM, Campus Coari, Estrada Coari Itapéua, \\ Km 2, s/n, Itamaraty, CEP 69460-000, Coari, AM, Brazil \\ 'Instituto Federal de Educação, Ciência e Tecnologia do Amazonas - IFAM, Campus Presidente Figueiredo, \\ Avenida Onça Pintada, 1308, CEP 69735-000, Presidente Figueiredo, AM, Brazil \\ ${ }^{d}$ Centro Universitário Nilton Lins, Universidade Nilton Lins, Avenida Professor Nilton Lins, 3260, Parque das Laranjeiras, \\ CEP 69058-040, Manaus, AM, Brazil \\ 'Faculdade Estácio do Amazonas, Avenida Constantino Nery, 3693, Chapada, CEP 69050-001, Manaus, AM, Brazil \\ ${ }^{\mathrm{f}}$ Empresa Brasileira de Pesquisa Agropecuária - EMBRAPA, Rodovia Juscelino Kubitschek, Km 5, 2600, \\ CEP 68903-419, Macapa, AP, Brazil \\ gInstituto Federal de Educação, Ciência e Tecnologia do Espírito Santo - IFES, Campus Piúma, \\ Rua Augusto Costa de Oliveira, 660, CEP 29285-000, Piúma, ES, Brazil \\ *e-mail: adriano.oliveira@ifam.edu.br
}

Received: April 6, 2016 - Accepted: May 26, 2016 - Distributed: November 31, 2017

(With 2 figures)

The crocodilians existing in Brazil belong to the family Alligatoridae (Cuvier, 1807). They are represented by six species: Caiman c. Crocodiles (Linnaeus, 1758), Caiman latirostris (Daudin, 1801), Caiman yacare (Daudin, 1801), Paleosuchus palpebrosus (Cuvier, 1807), Paleosuchus trigonatus (Schneider, 1801), and Melanosuchus niger (Spix, 1825), popularly known as black caiman (Costa and Bérnils, 2014).

The black caiman $M$. niger has a wide distribution in the Amazon River basin, including Brazil, Colombia, Ecuador, Bolivia, French Guiana, Guyana and Peru (Thorbjarnarson, 2010). In Brazil, this species occurs in all states of the Northern region and in two states of the Midwest Region (Goiás and Mato Grosso) (Marione et al., 2013).

Its environmental preferences are water bodies influenced by white water rivers from the Andes and rich in sediments (Junk et al., 2011), although they are also found as natural populations of dark water rivers (Silveira et al., 1997; Rebêlo and Lugli, 2001; Silveira et al., 2008) and artificial dams (Marione et al., 2013). However, throughout its extensive distribution area, this species occupies a wide range of wetlands, including torrential rivers and their backwaters, wetlands, flooded forests and seasonal savanna floodplains (Marione et al., 2013).

Amazonian crocodilians are predators at the top of the food chain, thus contributing to maintaining the ecological balance in their natural occurrence areas. Moreover, they are economically important, especially the use of the skin for making bags, shoes and other manufactured products. Besides, there is a trade of their meat, which is sold in markets (Sotero-Martins et al., 2015).

Among the various biological methods of scientific research, the analysis of blood constituents allows determining the health conditions of domestic and wildlife animals. Among infectious and parasitic diseases that hematological tests can diagnose, there are blood parasite diseases, which are transmitted by hematophagous insects (Lane and Mader, 1996). Among these hemoparasites, there is the filaria, which usually resides in lymph nodes. They mate and produce microfilariae, which is the first larval stage (Lane and Mader, 1996). Among microfilaria disease records, several studies were conducted with mammals. However, there is no record of the occurrence of microfilariae in the crocodilian blood. This can be useful in assessing the health status of $M$. niger native species samples. In this sense, this work aims to describe the first record of the occurrence of microfilaria and the prevalence in the blood of black caiman M. niger.

Ten black caiman M. niger specimens were collected in streams at the Daracuá community (Figure 1), located in the Mariuá Archipelago in the basin of the middle Rio Negro, near the town of Barcelos, Amazonas state, Brazil. The capture of the animals occurred in March and November 2014, periods of drought and low water, respectively. After the immobilization of the animals, the total length was determined using a metric tape, 


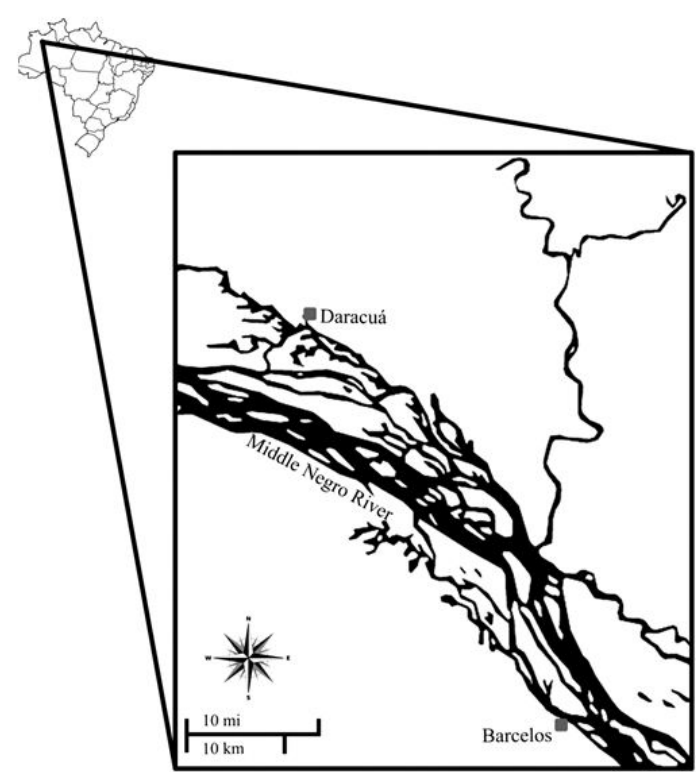

Figure 1. Location of capture of black caiman $M$. niger specimens, Daracuá Community, middle Rio Negro, Amazonas state, Brazil.

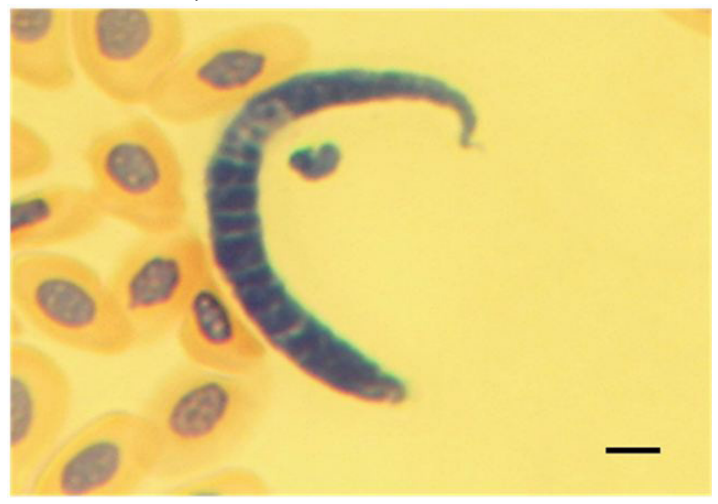

Figure 2. Microfilariae present in the blood of black caiman M. niger from the Daracuá Community, middle Rio Negro, Amazonas state, Brazil. Bar $=5.0 \mu \mathrm{M}$.

and then the blood was drawn by puncturing the arterial bulb (near the cervix) using syringes containing EDTA $(10 \%)$. The animals were released close to their capture location. Blood smears were prepared and stained with a May Grunwald-Giemsa-Wright solution. Observations of hemoparasites were performed in 20 fields with an optical microscope with binocular lenses.

The search for parasites in wild animals is an important tool to study the health of a population and the quality of the environment. It is thus possible to understand certain relations between the parasite-host and the environment in which it lives. In the present study, the animals had a total length of $46.1 \pm 21.1 \mathrm{~cm}$. The presence of microfilaria belonging to the superfamily Filarioidea were observed in $30 \%$ of the animals (Figure 2). In a study conducted by Maskey et al. (1998), unidentified nematodes $5 \mathrm{~mm}$ long were found in edematous kidneys of young gavials (Gavialis gangeticus Linnaeus, 1789) held in captivity. It was also reported that $67 \%$ of black caimans from the Mamirauá Development Reserve at the river Solimões, Amazonas state, had nematodes in the gastric mucosa and ulcers with hemorrhagic aspects. In some cases, there was even perforating ulcers in the serous layer of the stomach (Cardoso et al., 2013). This study shows the direct relation that exists among these microfilariae, which may affect the blood of $M$. niger from the middle Rio Negro.

Filaria parasites are reported in several animal species with different clinical implications, from serious illness to asymptomatic conditions. Studies show high microfilaria occurrence rates in wild animals, particularly those from the Northern region of Brazil. The significant percentage of animals infected by microfilariae show that the black caiman at the Daracuá community, middle Rio Negro, Amazonas state, are exposed to blood-sucking vectors and therefore occupy an ideal position to acquire blood parasites. One of the possible causes of the high rate of alligators infected with blood parasites could be the densification caused by the reduction of the river level in the period in which the animals were captured, as well as a correlation of hemoparasites with ecologically preserved environments.

\section{Acknowledgements}

This work was financed by Fundação de Amparo à Pesquisa do Estado do Amazonas (FAPEAM, process 062.02583/14). M. Tavares-Dias is research fellowship recipients from $\mathrm{CNPq} / \mathrm{Brazil}$.

\section{References}

CARDOSO, A.M.C., SOUZA, A.J.S., MENEZES, R.C., PEREIRA, W.L.A. and TORTELLY, R., 2013. Gastric lesions in free-ranging Black Caimans (Melanosuchus niger) associated with brevimulticaecum species. Veterinary Pathology, vol. 50, no. 4, pp. 582-584. PMid:22961885. http://dx.doi.org/10.1177/0300985812459337.

COSTA, H.C. and BÉRNILS, R.S., 2014. Répteis brasileiros: lista de espécies. Herpetologia Brasileira, vol. 3, no. 3, pp. 74-84.

JUNK, W.J., PIEDADE, M.T.F., SHÖNGART, J., COHN-HAFT, M., ADENEY, J.M. and WITTMAN, F., 2011. A Classification of major naturally-occuring Amazonian lowland wetlands. Wetlands, vol. 31, no. 4, pp. 623-640. http://dx.doi.org/10.1007/ s13157-011-0190-7.

LANE, T.J. and MADER, D.R., 1996. Parasitology in Reptile Medicine and Surgery. Philadelphia: WB Saunders Co, pp. 185-203.

MARIONE, B., FARIAS, I., VERDADE, L.M., BASSETI, L., COUTINHO, M.E., MENDONÇA, S.H.S.T., VIEIRA, T.Q., MAGNUSSON, W.E. and CAMPOS, Z., 2013. Avaliação do risco de extinção do jacaré-açu Melanosuchus niger (Spix, 1825) no Brasil. Biodiversidade Brasileira, vol. 3, no. 1, pp. 31-39.

MASKEY, T.M., KÖLLE, P., HOFFMANN, R., ANDERS, C.C. and SCHLEICH, H.H., 1998. Disastrous impact of intestinal infection in captive bred gharial hatchlings. Veröffentlichungen aus dem Fuhlrott-Museum, vol. 4, pp. 291-294. 
REBÊLO, G.H. and LUGLI, L., 2001. Distribution and abundance of four caiman species (Crocodilia: Alligatoridae) in Jaú National Park, Amazonas, Brazil. Revista de Biologia Tropical, vol. 49, no. 3-4, pp. 1095-1109. PMid:12189791.

SILVEIRA, R., MAGNUSSON, W.E., and CAMPOS, Z., 1997. Monitoring the distribution, abundance and breeding areas of Caiman crocodilus and Melanosuchus niger in the Anavilhanas archipelago, Central Amazonia. Journal of Herpetology, vol. 31, pp. 514-520. http://dx.doi.org/10.2307/1565603.

SILVEIRA, R., MAGNUSSON, W.E. and THORBJARNARSON, J.B., 2008. Factors affecting the number of caimans seen during spotlight surveys in the Mamirauá Reserva, Brazilian Amazonia.
Copeia, vol. 2, no. 2, pp. 425-430. http://dx.doi.org/10.1643/ CE-06-035.

SOTERO-MARTINS, A., JUNIOR, A.K., MARKENDORF, F., MARIONI, B., COIMBRA, R.F., FREIRE, G.M. and SILVEIRA, R., 2015. Riscos na qualidade sanitária da carne de jacaré da Amazônia Central. Vigilância Sanitária em Debate: Sociedade. Ciência \& Tecnologia, vol. 3, pp. 99-105.

THORBJARNARSON, J.B., 2010. Black caiman Melanosuchus niger. In: S.C. MANOLIS and C. STEVENSON, eds. Crocodiles: status survey and conservation action plan. 3rd ed. Darwin: Crocodile Specialist Group, pp. 29-39. 